\title{
Lessons from the Covid-19 pandemic: sustainability is an indispensable condition of Global Health Security
}

\author{
Deisy de Freitas Lima Ventura \\ Gabriela Marques di Giulio \\ Danielle Hanna Rached
}

${ }^{1}$ Postgraduate Program in Global Health and Sustainability, School of Public Health, University of São Paulo. Researcher PQ$\mathrm{CNPq} 1 \mathrm{~B}$

São Paulo/SP - Brasil

II Department of Environmental Health, School of Public Health, University of São Paulo São Paulo/SP - Brasil

Fundação Getúlio Vargas Rio de Janeiro Law School Rio de Janeiro/RJ - Brasil

\begin{abstract}
Among the possible developments of the Covid-19 pandemic at the international and national levels is the advancement of the Global Health Security (GHS) agenda. On the one hand, GHS might be able to give priority to health problems on the political agenda-setting, on the other, however, it might open up space for public security actors in decision-making processes to the detriment of the power of health authorities. This article critically analyzes the concept and the progress of the GHS agenda seeking to demonstrate that there can be no security in matters of public health when sustainability in its multiple dimensions is not taken into account. At the end, sustainability has a twofold responsibility: to maintain the consistency and permanence of emergency response actions, especially with investments in public health systems, with universal access, and to minimize the structural causes of pandemics linked to the environment.
\end{abstract}

Keywords: Global Health Security agenda, Covid-19, pandemic, sustainability

São Paulo. Vol. 23, 2020

Debating ideas

The COVID-19 epoch: Interdisciplinary research towards a new just and sustainable ethics

DOI: http://dx.doi.org/10.1590/1809-4422asoc20200108vu2020L3ID 


\section{Introduction}

Among the possible developments of the Covid-19 pandemic at the international level is the advancement of the Global Health Security (GHS) agenda. For the World Health Organization (WHO), GHS "is defined as the activities required, both proactive and reactive, to minimize the danger and impact of acute public health events that endanger people's health across geographical regions and international boundaries" (WHO, 2020a). According to such concept, defended by WHO, what is predominant is the interface between the public health and the security sectors (international organizations, civil defense, military doctors, law enforcement and armed forces). Environmental issues are mentioned, but are perceived more as causes of emerging and reemerging diseases, and less as conceptual aspects or possible instruments of GHS.

In the face of the overwhelming international spread of Covid-19 in the first months of 2020, the perception of the pandemic as a security problem tends to consolidate itself at the political level, occupying the agenda of international organizations, States and the biggest donors of international health cooperation (philanthropic foundations, private sector and developed states). It is likely that it will also grow in the academic sphere, with the induction of research and academic training priorities by funding agencies, high-impact international journals and academic partnerships between institutions.

This brief essay critically analyzes the progress of the GHS agenda, seeking to demonstrate that there can be no security in matters of public health when sustainability in its multiple dimensions is not taken into account, including social, ecological, economic, spatial, political, institutional and cultural aspects. If there is one important learning from the pandemic, it is that the synergy between the several systemic crises that characterize modernity, such as the loss of biodiversity and the climatic emergency, on the one hand, and the institutional, trust and responsibility crises, on the other (GIDDENS, 1999; BECK, 2010, MARQUES, 2020; 2016), now aggravated by the health crisis, reinforces the urgency of adopting a multidimensional and critical perspective of sustainability, which strengthens transformative pathways by a "new path capable of abandoning the political, social and economic New Deal” (MORIN, 2020, np). Such understanding of sustainability, which includes, among other critical elements, solidarity and shared responsibility for the planet's resources, human rights and a revised production and consumption models, is crucial to shape the GHS agenda.

To support our central argument, the essay first probes the definition of GHS. The Covid-19 pandemic is then presented as an example of the limits of a security approach attached to health surveillance and contingency plans during emergencies. Finally, the essay highlights the importance of sustainability to the GHS agenda, which is reinforced in two ways: by maintaining the consistency and permanence of emergency response actions, especially with investments in public health systems, with universal access, and by minimizing the structural causes of pandemics linked to the environment. 


\section{Probing the definition of GHS}

The concept of GHS is not new. At least with regard to infectious diseases. The international dimension of health security was already clear in the 14th century when quarantine was first used as an attempt to prevent bubonic plague from crossing borders (HEYMANN, 2015). The September 11, 2001 attacks in New York and the subsequent shipment of anthrax envelopes in the United States, in addition to the SARS outbreak that started in China, in 2002, made the international community realize the need to expand GHS's reach beyond infectious diseases. The adoption of the new International Health Regulations (IHR) in 2005 - in force since 2007, in 196 states - prompted the creation of the concept of Public Health Emergency of International Concern (PHEIC). Declared by the WHO Director-General, a PHEIC is defined as "an extraordinary event which is determined to constitute a public health risk to other States through the international spread of disease and to potentially require a coordinated international response" (WHO, 2005).

Covid-19 corresponds to the sixth PHEIC declared by WHO. In addition to it, there are two PHEICS currently underway: Poliovirus in regions with armed conflicts since 2014 (WHO, 2020c) and Ebola in the Democratic Republic of the Congo since 2019 (WHO, 2020b). Before it, there was the AH1N1 flu pandemic between 2009 and 2010, which originated in Mexico and was related to pork; the Ebola virus outbreak in West Africa, between 2014 and 2015; and, in 2016, the association between the Zika virus, neurological disorders, and congenital malformations, which has put Brazil at the epicenter of a PHEIC (VENTURA, 2016).

The Ebola outbreak in Western Africa was a turning point in the field of global health, fomenting a rich literature on the deficiencies of the international community, particularly the WHO, and generating numerous proposals for reform at the international and national levels. Although different from each other, these diagnoses and proposals have in common the idea that the world would not be prepared for the next PHEICs, including pandemics (GOSTIN; FRIEDMAN, 2015; SOON et al., 2015; WHO, 2015).

Also in 2014, under the coordination of the United States, a Global Health Security Agenda (GHSA) was created. The GHSA is a partnership of nations, international organizations, and civil society, with the mission to build countries' capacities to respond to infectious disease threats, especially to rapidly detect and control public health threats at their sources (GHSA, 2020). With scanty institutionalization, GHSA works basically by financing specific actions for each country, indicated by supposedly independent consultants. Currently bringing together 67 countries, the objectives of this alliance would be to emphasize global health security as a national leader-level priority and galvanize high-level commitments to global health security; promote multi-sectoral engagement and collaboration; and focus on common, measurable targets (GHSA, 2020). So far Brazil is not part of this agenda.

Although it presents itself as a means to carry out the obligations provided for by the IHR (FITZMAURICE et al., 2017), GHSA might in fact become a rival to the IHR and to the WHO itself. The obligations assumed by States under the IHR are complex, 
involving prevention, legislation, risk communication, laboratories, border control, rapid response capacity, etc. To fulfill these obligations, national health systems need to be strengthened. GHSA, on the other hand, is focused on developing only some of these capacities by the States, especially a surveillance system capable of raising international alarms in the face of the occurrence of an extraordinary event, allowing a disease to remain in the place where it emerged.

There is no doubt that GHSA provides health protection for the United States, but it also protects United States' economic interests, for example, to safeguard their exporting economy from disruptions to local, regional, and international markets and to national and state employment, trade, agriculture, travel, and tourism (BUNNELL, 2019; HOLST, 2020).

With the arrival of Donald Trump to the Presidency of the United States, there was a decline in North American investments in international cooperation, including in global health programs (HARMAN; DAVIES, 2019; YAMEY; GONSALVES, 2020). GHSA continued to function, but with less prominence than in the previous government (JENKINS, 2020). In view of the extraordinary dimension of the pandemic, the resumption of this agenda tends to happen, especially if a Democrat wins the presidency next year. Covid-19 may then confirm the dynamic of securitization of global health (NUNES, 2020), in the sense that a threat to public health might become a global security issue. If this happens, there might be a positive effect of giving priority to health problems on the political agenda-setting. But it might also have the negative effect of opening up space for public security actors in decision-making processes, to the detriment of the power of health authorities, which may cause that the logic of public security prevails over the logic of public health. It is necessary, therefore, to note the difference between processes of securitization of health issues, and processes that seek to achieve security through public health policies, as they will not always be synonymous.

A dangerous political practice that has been used frequently in the case of Covid-19 is to present governments' responses to pandemics through war metaphors. While it is critical that countries develop specific emergency response capacities and a pandemic requires extraordinary mobilization by States and societies, one should not condemn global health to an infinite succession of periods of "war" interspersed with "truces" focused on surveillance systems, rather than confronting the causes of the epidemics. If the immediate responses are not accompanied by structural changes, the question remains: "who will truly be safe at the end of each "war'?" (VENTURA, 2016).

\section{Covid-19 to reveal the limits of the GHSA}

A recent literature review on GHS (RAVI, 2019) indicates that the interaction between natural and built environments, such as climate and human and animal activities, has already appeared in academic production as a critical determinant of global health security. According to such review literature, the concept of "risk environment" (that is, the socioeconomic, political, regulatory and ecological factors that cause health insecurity) has become a useful paradigm for measuring the global health security of States. This 
concept also includes urbanization, changes in land use and the evolution of agricultural practices, due to its role in modulating the spread of diseases between humans and animals, and in creating conditions that allow the emergence of new zoonosis. Also to consider certain commercial practices and agricultural products - including swill feeding, illegal wildlife trade and the introduction of undeclared goods - which can further increase the risk of exposing emerging pathogens to susceptible human or animal populations.

Therefore, even for the specific literature on GHS, there are elements that indicate that a consistent, coherent understanding of global health must be developed in a way to integrate social and ecological objectives (VAN DE PAS, 2017). The risk is that the scientific production linking global health and sustainability will evolve in parallel with GHSA, and that it will remain in a more theoretical dimension, while the contingency plans and normative literature on GHS, which influence policy makers in reality, turn to short-term measures, in particular surveillance systems.

Studies released to date leave no doubt: "there is a single species that is responsible for the Covid-19 pandemic - us" (SETTELE et al., 2020). In a recent article, researchers who are part of the Intergovernmental Science-Policy Platform on Biodiversity and Ecosystem Services (IPBES) reinforce that, as with the climate and biodiversity crises, it is "a direct consequence of human activity - particularly our global financial and economic systems, based on a limited paradigm that prizes economic growth at any cost" (SETTELE et al., 2020). Rampant deforestation, uncontrolled expansion of agriculture, intensive farming, mining and infrastructure development, as well as the exploitation of wild species have created, according to them, a 'perfect storm' for the spillover of diseases from wildlife to people. Dealing with this and other future pandemics involve, according to such researchers, efforts to ensure the strengthening and enforcement of environmental regulations, stimulus packages that offer incentives for more sustainable and naturepositive activities, adoption a 'One Health' approach at all levels of decision-making (from the global to the local), funding health systems and incentivizing behavior change.

At the national context, the Covid-19 pandemic poses an even greater danger. The new correlation of forces in the Executive Branch, at the same time that it is resistant to the climate issue, expresses political support for predatory agricultural practices and proposes measures that legitimize deforestation in the Amazon, calling into question the future of the implementation of Agenda 2030 in Brazil. Researchers maintain that, in addition to social, economic and environmental damage, this stance can aggravate the impacts of Covid-19 and accelerate other future epidemics (FERREIRA et al., 2020; DECHOUM, 2020; LAPOLA, 2020). Its rapid evolution throughout the national territory, including its rapid escalation in the Amazon region, reveals how social inequities and the huge gaps that exist between the different social groups are reproduced in the intensity of the damage and in the number of deaths caused by the new coronavirus. Brazil remains a country that faces serious poverty and inequality issues, including inequalities in income distribution, access to education, health and housing services, and access to sanitation (CAMPELLO et al., 2018). About 13 million Brazilians live in favelas (The LANCET, 2020); $16.38 \%$ of Brazilians still do not have access to water supply networks and $46.85 \%$ 
do not have access to sewage networks (SNIS, 2019). The pandemic strongly highlights the need to find ways to reduce our pressure on natural systems, but it also reinforces the urgency to implement biosafety measures that reduce our vulnerability (DECHOUM, 2020), considering the regional differences and singularities of the social dynamics that characterize the Brazilian territory.

\section{GHS and Sustainability}

The pandemic has made clear that an efficient and ethically acceptable GHS is only possible if sustainability, in its multiple dimensions, is incorporated into it. As Nunes (2017) acknowledges, health security must accept the enormous planetary challenges brought by the Anthropocene, in particular the perspective of climate change, which presents the challenge of rethinking, as a global community, the global risks with strong local repercussions that characterize this era. Its driving forces are, ultimately, related to the capitalist exploitation of natural resources, the urbanized way of life and the development and intensive use of artifacts capable of altering the natural characteristics of the global system in a decisive and dangerous manner. And the pandemic, like so many other stories that earn global interest, has an underlying moral logic: the promotion of global common goods is inimical to, or sits uneasily with, an outright sovereignty-based and fragmented international order (KRISCH, 2010).

However, we should recognize that Covid-19 is simultaneously a public health emergency, a real-time experiment in downsizing the consumer economy, and a socioenvironmental disaster that may catalyze processes of social change (COHEN, 2020). It might reinforce a sustainable health security agenda allowing "the fundamental interconnection of human beings, other species and the planet, as well as the need for humanity to restart its consumption and behavior patterns" (NUNES, 2017). This agenda means inclusion, justice, awareness of differences and a reconsideration of current economic models based on incessant growth, consumption and waste (NUNES, 2017).

This new GHS and Sustainability agenda is in line with several critical studies (e.g. LOORBACH et al., 2017; MARQUES, 2016; COBBINAH et al. 2015; MARTINE et al., 2015; FERREIRA, 2011) that point out the need for alternative proposals when facing complex socio-environmental issues, and transformative change across technological, economic and social factors, promoting social and environmental responsibilities across all sectors. The challenge for both Covid-19 and other threats is, above all, the urgency of action. As argued by Marques (2020), the current pandemic is added to several systemic crises that threaten humanity, precisely at a time when it is no longer possible to postpone decisions that will crucially, and very soon, affect the planet's habitability. Surviving this and other threats, according to the author, involves "redefining our position as a society and as a species within the scope of the biosphere" (MARQUES, 2020). Latour (2020), however, is rather skeptical as to how the current health crisis could help people to be prepared for the climate change problem. According to him, the general mobilization against the virus "does not prove at all that we will be ready for the following mobilization".

If these issues are urgent, the process of encouraging academic production that 
addresses GHS to include, in fact, the prism of sustainability is also imperative. Such inclusion must happen in two ways. Sustainability must be linked to critical studies on the challenges and opportunities related to the consistency and permanence of emergency response actions, with a view to strengthening continuous investments in public health systems with universal access. However, sustainability should also be considered by a more focused literature on the structural causes of threats, such as Covid-19, with critical and interdisciplinary perspectives on the field with potential to influence the formulation of public policies and effective actions to enable structural and long-term solutions that promote equality, cohesion, social justice and transformative changes for a more adapted and sustainable future in order to end 'business as usual'.

The history of health crises has shown that the priority that was given to the Covid-19 pandemic will disappear with the end of the emergency. It reflects a cyclothymic global investment strategy, the object of which is unpredictable, depending on the emergency at hand (VENTURA et al, 2020). However, interdisciplinary research on emergencies and priority public health problems should be promoted continuously and systematically, and not only when such emergencies are occupying the headlines and triggering panic. Such measures would guarantee the quality of academic production and avoid the waste of scarce financial and human resources.

\section{References}

BECK, U. Sociedade de risco rumo a uma outra modernidade. 2. ed. São Paulo, Editora 34, 2010.

BUNNELL, R. et al. "Global Health Security: Protecting the United States in an Interconnected World." Public health reports, v. 134, n.1, p.3-10, 2009.

CAMPELO, T. et al. Faces da desigualdade no Brasil: um olhar sobre os que ficam para trás. Saúde em Debate, n. 42, p. 54-66, 2018.

COBBINAH, P. B.; ERDIAW-KWASIE, M. O.; AMOATENG, P. Rethinking sustainable development within the framework of poverty and urbanisation in developing countries. Environmental Development, n.13, p.18-32, 2015.

COHEN, M.J. Does the COVID-19 outbreak mark the onset of a sustainable consumption transition? Sustainability: Science, Practice and Policy, v. 16, n. 1, p.1-3, 2020.

DECHOUM, M.S. Pandemias, invasões biológicas e o mundo que queremos. Coalizão Ciência e Sociedade. 2020. Available from <http://cienciasociedade.org/pandemias-invasoes-biologicas-e-o-mundo-que-queremos/>. Access in: 13th, may, 2020.

FERREIRA, J. et al. A vulnerabilidade das populações do interior da Amazônia à Covid-19. Coalizão Ciência e Sociedade. 2020. Available from <http://cienciasociedade.org/a-vulnerabilidade-das-populacoes-do-interior-da-amazonia-a-covid-19/> . Access in: 13th, may, 2020. 
FERREIRA, L.C. (org). A questão ambiental na América Latina: teoria social e transdisciplinaridade. Campinas: Editora da Unicamp. 2011

FITZMAURICE, A. G. et al. Contributions of the US Centers for Disease Control and Prevention in Implementing the Global Health Security Agenda in 17 Partner Countries. Emerging infectious diseases, v. 23, n. 13, p. S15-S24, 2017.

GIDDENS, A. Risk and responsibility. Modern Law Review, Hoboken, v. 62, n.1, p. 1-10, 1999.

GLOBAL HEALTH SECURITY AGENDA (GHSA). Available from: https:/ghsagenda.org/ home/about-the-ghsa/ Access in: 11th, may, 2020.

GOSTIN, L.; FRIEDMAN, E. A retrospective and prospective analysis of the west African Ebola virus disease epidemic: robust national health systems at the foundation and an empowered WHO at the apex. The Lancet, n. 385, p. 1902-1909, 2015.

HARMAN, S.; DAVIES, S. President Donald Trump as global health's displacement activity. Review of International Studies v. 45, n. 3, p. 491-501, 2019.

HEYMANN, D. et al. Global health security: the wider lessons from the west African Ebola virus disease epidemic. The Lancet, v. 385, n. 9980, p. 1884-1901, 2015.

HOLST, J. Global Health - emergence, hegemonic trends and biomedical reductionism. Globalization and Health v.16, n. 42, p. 1-11, 2020.

JENKINS, B. Now is the time to revisit the Global Health Security Agenda. Brookings, March 27 2020. Available from: https:/www.brookings.edu/blog/order-from-chaos/2020/03/27/now-is-the-time-to-revisit-the-global-health-security-agenda/ Access in: 14th, may, 2020.

KRISCH, N. Global Administrative Law and the Constitutional Ambition. In: Dobner, P; Loughlin, M. (eds.). The Twilight of Constitutionalism? New York: Oxford University Press, p. 245-266, 2010.

LAPOLA, D. M. Futuras pandemias poderão começar no Brasil. Folha de S. Paulo. 2020. Available from: https://www1.folha.uol.com.br/opiniao/2020/05/futuras-pandemias-poderao-comecar-no-brasil.shtml Access in: 14th, may, 2020.

LATOUR, B. A crise sanitária incentiva a nos prepararmos para as mudanças climáticas, Le Monde, 25/03/2020. Available from: http://agbcampinas.com.br/site/2020/bruno-latour-a-crise-sanitaria-incentiva-a-nos-prepararmos-para-as-mudancas-climaticas/?fbclid=IwAR0zhkHTn TjrjzGMPQ96u3N7nDzebWWGxNxAwrcsAzEcWXrOCC8HU3vqlqM. Access in: 13th, may, 2020.

LOORBACH, D. et al. Sustainability Transitions Research: Transforming Science and Practice for Societal Change. Annu. Rev. Environ. Resour., n. 42, p. 599-626, 2017.

MARQUES, L. A pandemia incide no ano mais importante da história da humanidade. Serão as próximas zoonoses gestadas no Brasil? Ciência, Saúde e Sociedade: Covid-19. Available from: https://www.unicamp.br/unicamp/noticias/2020/05/05/pandemia-incide-no-ano-mais-importante-da-historia-da-humanidade-serao-proximas . Access in: 14th, may, 2020. 
MARQUES, L. Capitalismo e Colapso Ambiental. 2 ed. Campinas, Editora da Unicamp, 2016.

MARTINE, G.; ALVES, J. E. D. Economy, society and environment in the 21st century: three pillars or trilemma of sustainability? Revista Brasileira de Estudos de População, v. 32, n.3, p. 433-460, 2015.

MOON S. et al. Ebola change the game? Ten essential reforms before the next pandemic. The report of the Harvard-LSHTM Independent Panel on the Global Response to Ebola. The Lancet 2015, n. 386, p.2204-21, 2015.

MORIN, E. A mundialização é uma interdependência sem solidariedade. L'OBS, 19-25/3/2020 Entrevista concedida a David Le Bailey e Sylvain Courage. Tradução: Edgard de Assis Carvalho.

NUNES, J. A pandemia de COVID-19: securitização, crise neoliberal e a vulnerabilização global. Cad. Saúde Pública, Rio de Janeiro, v. 36, n. 5, p. e00063120, Mar. 2020.

NUNES, J. Segurança Sanitária Sustentável: da comunidade ao planeta. Saúde ao Sul, Instituto Suramericano de Gobierno en Salud (ISAGS), Rio de Janeiro, p. 5, Agosto de 2017.

RAVI, S. J. et al. Establishing a theoretical foundation for measuring global health security: a scoping review. BMC public health v. 19, n.1, p. 954, Jul. 2019.

SETTELE, J.; DÍAZ, S.; BRONDIZIO, E. COVID-19 - Stimulus Measures Must Save Lives, Protect Livelihoods, and Safeguard Nature to Reduce the Risk of Future Pandemics. Ipbes. 2020. Available from < https://ipbes.net/covid19stimulus >. Access in: 13th, may, 2020.

SNIS. Sistema Nacional de Informações sobre Saneamento. Available from < http://www.snis. gov.br/>. Access in: 14th, may, 2020.

THE LANCET. Editorial. COVID-19 in Brazil: "So what?". The Lancet, v. 395, n. 10235, p. $1461,2020$.

VAN DE PAS, R. Global Health in the Anthropocene: Moving Beyond Resilience and Capitalism. International journal of health policy and management v. 6, n. 8, p. 481-486, Aug. 2017.

VENTURA, D. F. L. et al. Desafios da pandemia de COVID-19: por uma agenda brasileira de pesquisa em saúde global e sustentabilidade. Cad. Saúde Pública, Rio de Janeiro, v. 36, n. 4, e00040620, Mar. 2020.

VENTURA, D. F. L. From Ebola to Zika: international emergencies and the securitization of global health. Cad. Saúde Pública, Rio de Janeiro, v. 32, n. 4, e00033316, 2016.

WHO. Health Security. 2020a. Available from < https://www.who.int/health-topics/health-security/\#tab=tab_1>. Access in: 14th, may, 2020.

WHO. International Health Regulations [2005]. 3 ed. Geneva: WHO, 2016. Available from < https://apps.who.int/iris/bitstream/handle/10665/246107/9789241580496-eng. pdf? sequence $=1>$. Access in: 14th, may, 2020 .

WHO. Statement of the Twenty-Third IHR Emergency Committee Regarding the International Spread of Poliovirus, 7 January 2020c. Available from < https://www.who.int/news-room/ 
detail/07-01-2020-statement-o-the-twenty-third-ihr-emergency-committee-regarding-the-international-spread-of-poliovirus >. Access in: 14th, may, 2020.

WHO. Statement on the 5th meeting of the International Health Regulations (2005) Emergency Committee for Ebola virus disease in the Democratic Republic of the Congo on 14 April 2020b. Available from < https://www.who.int/news-room/detail/14-04-2020-emergency-committee-for-ebola-virus-disease-in-the-democratic-republic-of-the-congo-on-14-april-2020>. Access in: 14th, may, 2020.

WORLD HEALTH ORGANIZATION (WHO). Ebola Interim Assessment Panel Report. Geneva: WHO, 2015. Available from < http://www.who.int/csr/resources/publications/ebola/ report-by-panel.pdf?ua $=1>$. Access in: 14th, may, 2020.

YAMEY, G.; GONSALVES, G. Donald Trump: a political determinant of covid-19. British Medical Journal, n. 369, p. m1643, 2020. 
Deisy de Freitas Lima Ventura

$\square$ deisy.ventura@usp.br

ORCiD: https://orcid.org/0000-0001-8237-2470
Submitted on: 22/05/2020

Accepted on: 25/05/2020

2020;23:e0108

\section{Gabriela Marques di Giulio}

घgiulio@usp.br

ORCiD: https://orcid.org/0000-0003-1396-9788

\section{Danielle Hanna Rached}

$\square$ danielle.rached@fgv.br

ORCiD: https://orcid.org/0000-0002-6759-3459

How to cite: VENTURA, D. F. L.; DI GIUIO; G. M.; RACHED; D. H. Lessons from the Covid-19 pandemic: sustainability is an indispensable condition of Global Health Security. Ambiente \& Sociedade. São Paulo, v. 23, p. 1-11, 2020. 


\title{
Lições da pandemia de Covid-19: a sustentabilidade é uma condição indispensável da Segurança da Saúde Global
}

\author{
Deisy de Freitas Lima Ventura \\ Gabriela Marques di Giulio \\ Danielle Hanna Rached
}

São Paulo. Vol. 23, 2020

Ideias em debate

A época $\mathrm{CO}$. VID-19: Pesquisa interdisciplinar $\mathrm{e}$ uma nova ética sustentável e justa
Resumo: Entre os possíveis desdobramentos da pandemia de Covid-19 nos âmbitos internacional e nacional encontra-se o avanço do tema da Segurança da Saúde Global (GHS em inglês). Por um lado, a evolução desta agenda pode ter o efeito positivo de destacar os problemas de saúde na agenda política; por outro, abre brechas para que atores da segurança pública dominem processos decisórios relativos à saúde pública, em detrimento das autoridades sanitárias. Este artigo analisa criticamente o conceito e a evolução da GHS, buscando demonstrar que não pode haver segurança em matéria de saúde pública quando a sustentabilidade não é levada em consideração em suas múltiplas dimensões. A sustentabilidade corresponde a uma dupla responsabilidade: manter a consistência e continuidade das ações de resposta às emergências, na perspectiva de assegurar investimentos contínuos nos sistemas públicos de saúde com acesso universal; e enfrentar as causas estruturais das pandemias relacionadas ao meio ambiente.

Palavras-chave: Segurança da Saúde Global, Covid-19, Pandemia, Sustentabilidade

Como citar: VENTURA, D. F. L.; DI GIUIO; G. M.; RACHED; D. H. Lições da pandemia de Covid-19: a sustentabilidade é uma condição indispensável da Segurança da Saúde Global. Ambiente $\mathbb{\&}$ Sociedade. São Paulo, v. 23, p. 1-11, 2020. 


\title{
Lecciones de la pandemia de Covid-19: la sostenibilidad es una condición indispensable de la Seguridad de la Salud Global
}

\author{
Deisy de Freitas Lima Ventura \\ Gabriela Marques di Giulio \\ Danielle Hanna Rached
}

São Paulo. Vol. 23, 2020

Ideas en debate

La época $\mathrm{CO}$.

VID-19: investigación interdisciplinaria y una nueva ética sostenible y justa
Resumen: Entre los posibles despliegues de la pandemia de Covid-19 en los planes internacional y nacional se encuentra el avance del tema de la Seguridad de la Salud Global (GHS en inglés). Por un lado, este fenómeno podría producir el efecto positivo de priorizar los problemas de salud en la agenda política; por otro, sin embargo, podría ampliar el espacio de actores de la seguridad en los procesos de toma de decisiones en salud pública. Este artículo analiza críticamente el concepto y la evolución reciente de la GHS, buscando demostrar que no hay seguridad en materia de salud sin tener en cuenta la sostenibilidad en sus múltiples dimensiones. Al final, concluye que la sostenibilidad corresponde a una doble responsabilidad: mantener la consistencia y la continuidad de la respuesta a emergencias, especialmente con inversiones en sistemas con acceso universal; y enfrentar causas estructurales de las pandemias relacionadas con el medio ambiente.

Palabras clave: Seguridad de la Salud Global, Covid-19, Pandemia, Sostenibilidad

Como citar: VENTURA, D. F. L.; DI GIUIO; G. M.; RACHED; D. H. Lecciones de la pandemia de Covid-19: la sostenibilidad es una condición indispensable de la Seguridad de la Salud Global. Ambiente \& Sociedade. São Paulo, v. 23, p. 1-11, 2020. 